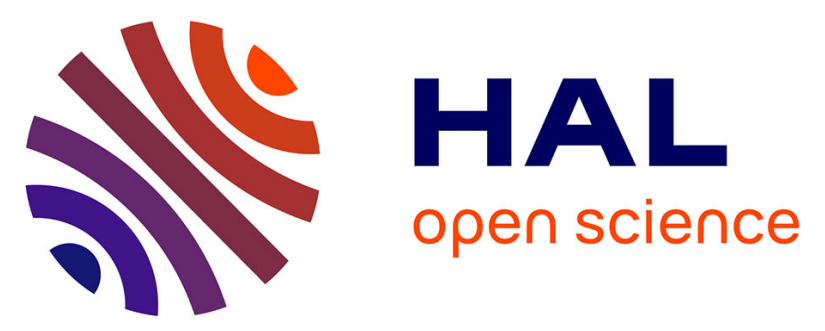

\title{
Novel TSHR mutations in consanguineous families with congenital non-goitrous hypothyroidism
}

Hakan Cangul, Neil V Morgan, Julia R Forman, Halil Saglam, Zehra Aycan, Tahsin Yakut, Tuna Gulten, Omer Tarim, Ece Bober, Yasar Cesur, et al.

\section{- To cite this version:}

Hakan Cangul, Neil V Morgan, Julia R Forman, Halil Saglam, Zehra Aycan, et al.. Novel TSHR mutations in consanguineous families with congenital non-goitrous hypothyroidism. Clinical Endocrinology, 2010, 73 (5), pp.671. 10.1111/j.1365-2265.2010.03849.x . hal-00583581

\section{HAL Id: hal-00583581 \\ https://hal.science/hal-00583581}

Submitted on 6 Apr 2011

HAL is a multi-disciplinary open access archive for the deposit and dissemination of scientific research documents, whether they are published or not. The documents may come from teaching and research institutions in France or abroad, or from public or private research centers.
L'archive ouverte pluridisciplinaire HAL, est destinée au dépôt et à la diffusion de documents scientifiques de niveau recherche, publiés ou non, émanant des établissements d'enseignement et de recherche français ou étrangers, des laboratoires publics ou privés. 


\section{CLINICAL ENDOCRINOLOGY}

\section{Novel TSHR mutations in consanguineous families with congenital non-goitrous hypothyroidism}

\begin{tabular}{|c|c|}
\hline Journal: & Clinical Endocrinology \\
\hline Manuscript ID: & CEN-2010-000238.R2 \\
\hline Manuscript Type/Office: & 1 Original Article - UK/Europe \\
\hline $\begin{array}{r}\text { Date Submitted by the } \\
\text { Author: }\end{array}$ & 02-Jul-2010 \\
\hline Complete List of Authors: & $\begin{array}{l}\text { Cangul, Hakan; University of Birmingham, School of Clinical and } \\
\text { Experimental Medicine, Medical \& Molecular Genetics } \\
\text { Morgan, Neil V; University of Birmingham, School of Clinical and } \\
\text { Experimental Medicine, Medical \& Molecular Genetics } \\
\text { Forman, Julia R; Institut Pasteur, Structural Bioinformatics Unit } \\
\text { Saglam, Halil; Uludag University School of Medicine, Department of } \\
\text { Paediatric Endocrinology } \\
\text { Aycan, Zehra; Dr Sami Ulus Woman Health, Children Research } \\
\text { Hospital, Division of Paediatric Endocrinology } \\
\text { Yakut, Tahsin; Uludag University School of Medicine, Department of } \\
\text { Medical Genetics } \\
\text { Gulten, Tuna; Uludag University School of Medicine, Department of } \\
\text { Medical Genetics } \\
\text { Tarim, Omer; Uludag University School of Medicine, Department of } \\
\text { Paediatric Endocrinology } \\
\text { Bober, Ece; Dokuz Eylül University, Faculty of Medicine, } \\
\text { Department of Paediatrics, Division of Endocrinology } \\
\text { CESUR, Yasar; Faculty of Medicine, Yüzüncü Yıl University, } \\
\text { Departments of Pediatric Endocrinology } \\
\text { Kirby, Gail A; University of Birmingham, School of Clinical and } \\
\text { Experimental Medicine, Medical \& Molecular Genetics } \\
\text { Pasha, Shanaz; University of Birmingham, School of Clinical and } \\
\text { Experimental Medicine, Medical \& Molecular Genetics } \\
\text { Karkucak, Mutlu; Uludag University School of Medicine, Department } \\
\text { of Medical Genetics } \\
\text { Eren, Erdal; Uludag University School of Medicine, Department of } \\
\text { Paediatric Endocrinology } \\
\text { Bas, Veysel; Dr Sami Ulus Woman Health, Children Research } \\
\text { Hospital, Division of Paediatric Endocrinology } \\
\text { Demir, Korcan; Dokuz Eylül University, Faculty of Medicine, } \\
\text { Department of Paediatrics, Division of Endocrinology }\end{array}$ \\
\hline Key Words: & $\begin{array}{l}\text { congenital hypothyroidism, consanguineous, mutation, TSHR, gene } \\
\text { mapping }\end{array}$ \\
\hline
\end{tabular}




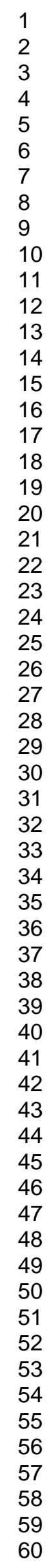

\section{ScholaroNE" \\ Manuscript Central}




\section{Novel TSHR mutations in consanguineous families with congenital non-goitrous hypothyroidism}

Short title: Novel TSHR mutations in congenital hypothyroidism

Hakan Cangul $^{1,2}$, Neil V Morgan ${ }^{1}$, Julia R Forman ${ }^{3}$, Halil Saglam ${ }^{4}$, Zehra Aycan ${ }^{5}$, Tahsin Yakut ${ }^{2}$, Tuna Gulten ${ }^{2}$, Omer Tarim ${ }^{4}$, Ece Bober ${ }^{6}$, Yasar Cesur ${ }^{7}$, Gail A Kirby ${ }^{1}$, Shanaz Pasha ${ }^{1}$, Mutlu Karkucak ${ }^{2}$, Erdal Eren ${ }^{4}$, Semra Cetinkaya ${ }^{5}$, Veysel Bas ${ }^{5}$, Korcan Demir $^{6}$, Sevil A Yuca ${ }^{7}$, Esther Meyer ${ }^{1}$, Michaela Kendall ${ }^{8}$, Wolfgang Hogler ${ }^{9}$, Timothy G Barrett ${ }^{1,9}$, Eamonn R Maher ${ }^{1}$

1 Department of Medical and Molecular Genetics, School of Clinical and Experimental Medicine, University of Birmingham, Birmingham B15 2TT, UK

2 Department of Medical Genetics, School of Medicine, Uludag University, Bursa 16059, Turkey

3 Institut Pasteur, Structural Bioinformatics Unit, 75015 Paris, France

4 Department of Paediatric Endocrinology, School of Medicine, Uludag University, Bursa 16059, Turkey

5 Division of Paediatric Endocrinology, Dr Sami Ulus Woman Health, Children Research Hospital, Ankara, Turkey

6 Division of Endocrinology, Department of Paediatrics, Faculty of Medicine, Dokuz Eylül University, Izmir, Turkey.

7 Division of Paediatric Endocrinology, Faculty of Medicine, Yuzuncu Yil University, Van, Turkey 
Department of Public Health, School of Medicine, Uludag University, Bursa 16059, Turkey

9 Department of Endocrinology and Diabetes, Birmingham Children's Hospital, Birmingham, UK

\section{Correspondence:}

Dr Hakan Cangul

Department of Medical and Molecular Genetics

School of Clinical and Experimental Medicine

University of Birmingham

Birmingham B15 2TT United Kingdom

E-mail: $\underline{\text { h.cangul@bham.ac.uk }}$

Fax: +44 (0) 1216272618

Key words: TSHR, congenital hypothyroidism, consanguineous, gene mapping, mutation

\section{Acknowledgments}

We thank NewLife, WellChild and the Wellcome Trust for financial support. HC was partly supported by European Union under its Framework 7 programme, FP7-PEOPLE2009-Marie Curie IEF. JRF was sponsored in part by a grant from the Pasteur Foundation of New York. We also thank families for their help with this research. Authors declared no conflicting interests.

Word count: 3,457 


\begin{abstract}
Objective: Non-syndromic autosomal recessively inherited non-goitrous congenital hypothyroidism (CHNG) can be caused by mutations in TSHR, PAX8,TSHB, and NKX25. We aimed to investigate mutational frequencies of these genes and genotype/phenotype correlations in consanguineous families with CHNG.

Design: Since consanguinity in individuals with a presumptive genetic condition is often an indicator of an autosomal recessive inheritance and allows firmer correlations to be established between genotype and phenotype, we planned to execute our study in consanguineous families.
\end{abstract}

Patients: 139 children with CHNG phenotype born to consanguineous families.

Measurements: First we investigated cases for evidence of linkage to the four knownCHNG genes by microsatellite marker analysis. Mutation analysis by direct sequencing was then performed in those cases in whom linkage to the relevant candidate gene could not be excluded. In addition in silico analysis of the predicted structural effects of TSHR mutations was performed and related to the mutation specific disease phenotype.

Results: Homozygous germline TSHR mutations were detected in 6 families (5\%), but no mutations were detected in PAX8,TSHB, and NKX2-5. Four of TSHR mutations had not previously been described. Genotype-phenotype correlations were established and found to be related to the predicted structural effects of the mutations.

Conclusions: Known-causative genes account for the development of CHNG only in a minority of cases and our cohort should provide a powerful resource to identify novel causative genes and to delineate the extent of locus heterogeneity in autosomal recessively inherited $\mathrm{CHNG}$. 


\section{INTRODUCTION}

Congenital hypothyroidism $(\mathrm{CH})$ is the most common neonatal metabolic disorder with an incidence of 1 in 3000 to 4000 live births and, if untreated, results in severe neurodevelopmental impairment and infertility. Worldwide the most frequent cause of hypothyroidism, including congenital forms, is iodine deficiency. However, particularly in areas where dietary iodine is adequate, developmental defects of the hypothalamicpituitary-thyroid axis are the main important cause of $\mathrm{CH}$. Thus $\mathrm{CH}$ is most often caused by defects in thyroid development leading to thyroid dysgenesis $(85 \%)$ [which can be subdivided into thyroid agenesis (40\% of all cases), failure of the gland to descend normally during embryological development with or without ectopy (40\%), or hypoplasia of a eutopic gland] and the remaining cases are associated with either goitre or a normal thyroid gland. Rarely, central (secondary/tertiary) hypothyroidism may be caused by pituitary or hypothalamic disease leading to deficiency of thyrotropin (TSH) or thyrotropin releasing hormone (TRH), respectively ${ }^{1,2}$.

In this study we focused on primary non-goitrous congenital hypothyroidism (CHNG) likely to be caused by single gene defects. Therefore we executed our study in consanguineous families in whom recessive gene defects are the most likely cause for the development of the disease. In OMIM database four clinical entries with known genetic causes, CHNG 1, 2, 4, and 5, have been described to date (MIM numbers 275200, 218700, 275100, and 225250 respectively). The causative genes for these are respectively $T S H R, P A X 8, T S H B$, and $N K X 2-5$. There is one additional locus on 
chromosome $15 \mathrm{q} 25.3$ causing CHNG 3 for which the causative gene is yet to be identified.

The presence of parental consanguinity in individuals with a presumptive genetic condition is often an indicator of an autosomal recessive inheritance. In consanguineous families with autosomal recessively inherited disorders there is a high likelihood of mutation homozygosity (both parents having inherited the same mutation from a common ancestor) and so autozygosity mapping can provide a powerful strategy to map regions containing a disease gene. Conversely, candidate genes that are not contained within an autozygous segment are unlikely to cause the relevant disorder. We have ascertained a large cohort of consanguineous families $(n=120)$ with non-goitrous congenital hypothyroidism (CHNG) and have undertaken genetic mapping and mutation analysis studies for four candidate genes (TSHR, PAX8,TSHB, and NKX2-5). We identified four novel and two previously reported TSHR mutations but most cases were not linked to any known CHNG genes. 


\section{MATERIALS AND METHODS \\ Subjects}

We collected blood samples from a total of 139 cases from 120 consanguineous families with primary non-syndromic $\mathrm{CH}$ without evidence of goitre or auto-immune thyroid disease. Families in which autosomal dominant inheritance was suspected, with at least one parent affected, were excluded from the study. Cases with clear evidence of central hypothyroidism were also excluded and almost all cases had elevated TSH levels at the time of diagnosis (range between 33 and $1578 \mathrm{mIU} / \mathrm{L}$ ), levels for some cases not being available. Tissue scans showed a spectrum of thyroid morphologies ranging from agenesis to normal sized gland but none of the cases had enlarged gland at the time of diagnosis. 40 consanguineous families were recruited through the West Midlands Regional Clinical Genetics Service in Birmingham, UK. Most of these families were originated from the Mirpur region of Pakistan in whom $\mathrm{CH}$ occurs at an unusually high rate (1:770 live births). In addition 80 consanguineous Turkish families with CHNG were ascertained through four large clinical centres in Turkey where consanguinity rates are high. All families gave informed consent and the study was approved by local ethics committees. This study was conducted according to the principles stated in the Declaration of Helsinki. DNA was extracted by using standard methods and stored at $20^{\circ} \mathrm{C}$ until analysed.

\section{Microsatellite marker analysis}

Initially cases were genotyped by using microsatellite markers (short tandem repeatsSTRs) that closely flank the existing loci for CHNG (see Table 1). Even though we 
excluded the cases with clear evidence of central hypothyroidism, TSHB locus was still included in the analyses since hormone levels were not available for some cases, and also since some $T S H B$ mutations can completely abolish the bioactivity but resulting mutant molecule can still form heterodimer with the alpha-subunit and preserve immunoreactivity in some TSH measurement methods. Therefore variable TSH levels could be detected in patients with TSHB mutations depending on the method used. In families with two or more affected siblings, microsatellite marker analyses of all family members were carried out to observe the segregation of conserved haplotypes. Standard polymorphic microsatellite markers (UniSTS; http://www.ncbi.nlm.nih.gov) were used for each of the causative loci investigated. Overall genotypes for 24 markers were determined for each patient, including eight markers for the CHNG3 locus. Table 1 shows the details of the causative genes examined and the markers used for each locus. One oligonucleotide of each primer pair was fluorescently labelled (5 HEX or TET or FAM) and genomic DNA samples at a concentration of $20 \mathrm{ng} / \mu \mathrm{l}$ were amplified by using these primers in a Tetrad 2 PCR machine (Bio-Rad, USA). Fluorescently-labelled PCR products then were loaded onto ABI 3730 DNA capillary electrophoresis machine in a 96-well plate format and subsequent data was analysed with the use of ABI Prism GeneMapper ${ }^{\mathrm{TM}}$ v3.0 software suite. The haplotypes, i.e. set of closely linked alleles inherited as a unit, were deduced for all patients. When an affected individual was homozygous for the haplotypes closely surrounding a region where a disease gene is located, i.e. both haplotypes derived from the two homologous chromosomes are identical, this was taken as suggestive of linkage whereas heterozygosity was considered as the proof of no-linkage. 


\author{
Mutation analysis of the known-causative genes in cases with positive linkage \\ In families with potential linkage to a known-CHNG gene (TSHR, PAX8, TSHB, and \\ $N K X 2-5)$ we then proceeded to perform mutation analysis of the relevant gene by direct \\ sequencing. Each gene was investigated by sequencing of all exons and intron-exon \\ boundaries on an ABI Prism 3730 DNA Analyzer, using the ABI BigDye Terminator \\ v3.1 Cycle Sequencing kits. Primer pairs were designed for exon-specific PCR \\ amplification of all exons of four causative genes. At the purification stage, amplified \\ products were either treated with microCLEAN (Microzone Ltd) or gel-extracted \\ (Qiagen). DNA sequences were viewed and analysed using Chromas software.
}

\title{
RT-PCR
}

In one family a homozygous germline TSHR exon 2 deletion was suspected, and we proceeded to investigate the status of the TSHR transcript between exons 1 and 3. Thus we extracted RNA from all family members, synthesized their cDNA, and performed PCR and sequencing reactions with primers covering the region between the end of exon 1 and the beginning of exon 3. Total RNA was extracted from lymphocytes using the RNeasy Mini Kit (Qiagen), and then cDNA was synthesized using random primers and AMV reverse transcriptase using the Promega reverse transcription system A3500 according to manufacturers' instructions (Promega). The primers used for RT-PCR and sequencing reactions were: TSHR_1_FOR (5'-GAGAAATAGCCCCGAGTCCC-3') and TSHR_3_REV (5’'-GAGTCACTTTACTCAAATTG -3’'). 


\section{Structural prediction model for missense mutations}

To analyse the likely structural effects of the missense mutations identified in this work, we considered their evolutionary conservation, as illustrated by a multiple alignment of the top 50 Blast hits (performed using the Uniprot server). We also examined potential intermolecular interactions, to determine if they would be disrupted upon mutation.

TSHR is a G-coupled receptor with 764 amino acids, comprised of a large, extracellular leucine-rich repeat domain which binds the hormone, and a transmembrane domain with seven helices. Sanders et al. ${ }^{3}$ solved the crystal structure of the extracellular domain, residues 1-213, in complex with a thyroid-stimulating antibody (PDB code 3G04). The transmembrane domain structure is not known, however the bovine rhodopsin structure (e.g. PDB code $1 \mathrm{GZM}^{4}$ ) provides a suitable template for analysis or homology modelling (based on GRIS ${ }^{5}$ and swissmodel.expasy.org ${ }^{6}$ ). In addition, given the sequence similarity between TSHR and FSHR, the structure of the FSH/FSHR complex (PDB code $1 \mathrm{XWD}^{7}$ ) suggests the most likely binding site of TSH with TSHR. Also, there is evidence that TSHR functions as a homodimer. To consider the structural effects on dimerisation, we analysed the dimer contacts of a published model of dimeric bovine rhodopsin $\left(1 \mathrm{~N} 3 \mathrm{M}^{8}\right)$. Finally, individual missense mutations may destabilise a protein domain, even to the extent of preventing folding. To consider this effect, we predicted quantitative stability changes $\left(\Delta \Delta \mathrm{G}_{\mathrm{D}-\mathrm{N}}\right)$ with the software tool $\mathrm{SDM}^{9}$ (http://mordred.bioc.cam.ac.uk/ sdm/ sdm.php). 


\section{RESULTS}

Genotyping with 16 microsatellite markers associated with the TSHR, TSHB, PAX8 and NKX2-5 genes (see Table 1) was performed in 139 individuals with CHNG (44 of Pakistani origin and 95 of Turkish origin). Heterozygosity of the disease genes was detected in 65 cases (13 of Pakistani origin and 52 of Turkish origin) from a total of 37 kindreds. Details of the number of affected individuals and genes for which linkage could not be excluded are shown in Table 2 .

Direct sequencing of the TSHR gene was performed in 24 individuals from 16 kindreds in whom linkage to TSHR could not be excluded. Germline TSHR mutations were characterised in 6 kindreds (see Table 3). A homozygous G to A transition at codon 553 of the TSHR gene, causing substitution of an alanine residue by a threonine (A553T) was detected in two affected siblings from a family of Pakistani origin (B1). The parents and an unaffected sibling were heterozygous for this missense mutation confirming the segregation of the disease allele. Both affected children showed absent $\mathrm{I}^{133}$ uptake in thyroid scintigraphy but had severely hypoplastic glands on ultrasonography at the time of diagnosis. Our studies showed that this mutation was significantly destabilising $\left(\Delta \Delta \mathrm{G}_{\mathrm{D}-\mathrm{N}}-2.7\right)$ and that the Ala553 residue was conserved for 49 of the 50 sequences in our alignment.

\footnotetext{
A homozygous splice site mutation c.317+1G $>$ A was identified in a Turkish family with two affected children (T1) and it segregated with disease status (both parents and an
} 
unaffected sib were heterozygous). Both cases carrying this novel mutation had apparent thyroid aplasia on US scan.

Three different homozygous missense mutations were detected in 3 Turkish families with a single affected individual (see Table 3). None of these 3 mutations were detected in 340 ethnically matched control chromosomes and each segregated with disease status. Family T2 with a homozygous p.Pro556Arg mutation presented when the proband was 3 months old. At the time of diagnosis a TSH level of $>100 \mu \mathrm{U} / \mathrm{mL}$ (normal $<20 \mu \mathrm{U} / \mathrm{mL}$ ) and a $\mathrm{FT}_{4}$ level of 0,4 ng/dL (normal 0,8-1,9 ng/dL) were detected, and thyroid gland was not detected on scintigraphy or US scan. Even though treatment immediately started at the age of 3 months, the 11 year-old case now shows moderate mental retardation. At age 11 years a US scan showed an apparently absent right thyroid lobe and a very hypoplastic left lobe. We note that the proline556 residue is conserved in all of the 50 sequences in our alignment and located at the end of a transmembrane helix.

Two of the mutations characterised in this study (p.Pro162Ala and p.Arg531Trp) were associated with a milder phenotype. The case from family T3 had the missense mutation p.Pro162Ala and was diagnosed with a moderately high TSH level (48 $\mu \mathrm{U} / \mathrm{mL})$ in neonatal screening and had normal thyroid scintigraphy and US scan with euthyroid hormone levels. Our structural predictions suggested that p.Pro162Ala would only cause a mild destabilisation $\left(\Delta \Delta \mathrm{G}_{\mathrm{D}-\mathrm{N}}-0.7\right)$ in the receptor molecule and slightly disrupt ligand binding. The other mild missense mutation p.Arg531Trp was detected in family T4 and the case had a mildly elevated level of TSH (33,3 mIU/L), a normal level of FT4 (1.3 
$\mathrm{ng} / \mathrm{dL}$ ), and a thyroid gland of normal size and location in US scan at the time of diagnosis. Our SDM predictions suggested that p.Arg531Trp mutation might slightly disrupt the dimerisation of the receptor molecule.

In family T5 exon 2 of the TSHR gene failed to amplify in the two affected siblings. Analysis of the TSHR transcript by RT-PCR revealed two differently sized fragments in the parents. In cDNA derived from blood of both affected children only the smaller fragment (268 bp) was detected whereas both parents and an unaffected sibling also expressed a larger (340 bp) fragment (which corresponded to the expected size).

Sequencing confirmed that the $340 \mathrm{bp}$ fragment contained exon 1, 2 and 3 sequence whereas the $268 \mathrm{bp}$ fragment did not include exon 2 (Figure 1). These findings were consistent with a homozygous exon 2 deletion in the two affected children.

Phenotypically, the older sibling had no activity in thyroid scintigraphy and a hypoplastic gland on US scan but hormone levels at diagnosis were not available. The younger sibling had a TSH level of $1578 \mathrm{mIU} / \mathrm{L}$ and a FT4 level of $0,16 \mathrm{ng} / \mathrm{dL}$ at the time of diagnosis, and his US scan detected a very hypoplastic thyroid tissue.

No mutations were detected in the TSHB, PAX8 and NKX2-5 in the patients in whom linkage to one or more of these genes could not be excluded. 


\section{Predicted structural consequences of missense mutations detected}

SDM scores (for predicted effect on protein stability) for each of the missense mutations detected in this study are summarised in Table 4. Mutation Pro162Ala is predicted to be only mildly destabilising $\left(\Delta \Delta \mathrm{G}_{\mathrm{D}-\mathrm{N}}-0.7\right)$. However, it is conserved in all of the TSHRs in our alignment. To consider its intermolecular interactions, we examined the interactions of the equivalent residue, Ile155, in the FSH/FSHR complex (PDB code $1 \mathrm{XWD}^{7}$, Figure 2). There are no known direct contacts, however it is in the local environment of the binding site so we predict it could slightly disrupt binding. The remaining missense mutations were found in three sites in the transmembrane domain. As the structure was not available, the stability predictions were made for the mutations at equivalent positions in bovine rhodopsin (PDB code $1 \mathrm{GZM}^{4}$; see Table 4 and Figure 3; equivalent positions were found using an alignment made using Uniprot ${ }^{10-11}$ and the alignments could be seen in Supplements 1 and 2)

Residue Arg531 was conserved in all of the TSHRs in our alignment. Mutation Arg531Trp (Phe146 in bovine rhodopsin) is predicted to be slightly stabilising $\left(\Delta \Delta \mathrm{G}_{\mathrm{D}-\mathrm{N}}\right.$ 1.3), while Arg531Glu is predicted to be significantly destabilising $\left(\Delta \Delta \mathrm{G}_{\mathrm{D}-\mathrm{N}}-2.1\right)$. The equivalent site in bovine rhodopsin, Phe146, is at the dimer interface, so these mutations may act by disrupting dimerisation. Residues Ala553 and Pro556 (Ala168 and Pro171 in bovine rhodopsin, respectively) are both buried, and therefore do not make any intermolecular contacts, however the bovine rhodopsin equivalent residues are found in one of the helices at the dimer interface (as modelled in $1 \mathrm{~N} 3 \mathrm{M}^{8}$ ). Ala553Thr (Ala168Thr in bovine rhodopsin) is predicted to be significantly destabilising $\left(\Delta \Delta \mathrm{G}_{\mathrm{D}-\mathrm{N}}-2.7\right)$. In 
addition, the alanine is conserved for 49 of the 50 sequences in our alignment (the only exception is Danio rerio TSHR, with glycine in the equivalent position). Pro556Arg and Pro556Leu (at the Pro171 site in bovine rhodopsin) are predicted by SDM to be neutral and disease-associated mutations, respectively $\left(\Delta \Delta \mathrm{G}_{\mathrm{D}-\mathrm{N}} 0.7\right.$ and 3.45). However, proline is conserved at this site in all of the sequences in our alignment, and is found at the end of a helix, suggesting it is structurally required at this site. 


\section{DISCUSSION}

Congenital hypothyroidism is the most common preventable cause of mental retardation. Therefore early and accurate diagnosis of the disease is of crucial importance for timely therapeutic intervention. In this study we performed linkage and mutation analysis of four known causative genes for CHNG (TSHR, PAX8, TSHB, and NKX2-5) in a large cohort of patients with $\mathrm{CHNG}$ phenotype from consanguineous families.

Individuals with autosomal recessively inherited disorders born into consanguineous families are most likely to be homozygous for a mutation inherited from a common parental ancestor. This observation is the basis for using an autozygosity mapping strategy to identify disease genes for recessively inherited disorders. Conversely the finding of heterozygosity at microsatellite markers flanking a disease gene makes it unlikely that the gene contains a mutation. In order to prioritise patients for gene sequencing we initially typed affected individuals for 16 microsatellite markers linked to the four disease genes. Whilst this might have excluded some patients who (despite being from consanguineous families) were compound heterozygotes or who harboured a homozygous mutation within a small region of autozygosity, such patients are likely to be infrequent. Mutation analysis demonstrated that $15 \%$ of the families with thyroid dysgenesis carried a TSHR mutation but no mutation was detected for the other three genes tested in our cohort. To our knowledge, we report the first large (exonic) deletion of TSHR. The exon 2 deletion is predicted to cause an in frame deletion (IFD) and skipping of exon 2 in the transcript. However this mutation would not have been detected if the probands had been heterozygous and our finding suggests that techniques that can 
reliably detect heterozygous exonic deletions (e.g. MLPA) should have a role in TSHR mutation testing.

As expected, all six consanguineous kindreds had homozygous TSHR mutations. The finding of homozygosity for a mutation facilitates the elucidation of genotype-phenotype correlations. The p.Ala553Thr missense mutation identified in family B1 was originally described in a consanguineous Moroccan family with two affected siblings in whom initial physical examination and ${ }^{99 \mathrm{~m}} \mathrm{Tc}$ scintigraphy failed to demonstrate the presence of thyroid tissue (leading to an incorrect diagnosis of athyreosis) but subsequent ultrasonography (US) revealed the presence of a very hypoplastic thyroid tissue in normal position in both cases ${ }^{12}$. Similarly in our study this mutation was associated with a severe phenotype and our results indicated highly destabilising nature of this alteration and high degree of conservation of the altered residue. These results combined with the in vitro observations showing that the expression of the mutant protein in transfected cell lines ${ }^{12-}$ ${ }^{17}$ is associated with very low expression of the mutant protein at the cell surface, are consistent with the severe phenotype associated with this mutation. The novel c. $317+1 \mathrm{G}>\mathrm{A}$ splice site mutation was also associated with a very severe phenotype, indicating a deleterious effect of this alteration on the resulting receptor.

\footnotetext{
The missense mutation p.Pro556Arg detected in family T2 was associated with a severe phenotype, suggesting a critical role for this residue in the structure of the molecule. Even though this change was not previously reported, another missense mutation at the same site (p.Pro556Leu) was characterised in severely hypothyroidic hyt/hyt mice and
} 
functional investigations showed that this substitution totally abolished TSH binding and receptor function ${ }^{18}$. In vitro studies also revealed that p.Pro556Leu eliminated G proteincoupled cAMP production and cAMP-responsive reporter gene expression. Overall these data support the association of this mutation with the severe phenotype observed in our patient.

The missense mutation p.Pro162Ala associated with a mild phenotype in family T3 was previously described as a loss-of-function mutation and heterozygous carriers of this mutation had mild resistance to TSH manifesting as euthyroidism with slight hyperthyrotropinemia ${ }^{19-21}$. There have been only a few previous reports of homozygous individuals for this mutation and all four cases coming from three different consanguineous families had moderately elevated TSH levels $(<100 \mu \mathrm{U} / \mathrm{mL})$ with normal thyroid radioiodine scan and $\mathrm{FT}_{4}$ levels at normal range ${ }^{22-24}$. Similar phenotypic features of our case provide further evidence for the association of this mutation with a moderate TSH resistance. The other mild missense mutation detected in family T4, p.Arg531Trp, is the first naturally occurring homozygous mutation reported to date at this site. An alternative missense substitution at the same residue was investigated previously in an in vitro functional study ${ }^{25}$ and Feng et al. identified a motif in the second intracellular loop (IL2) of the TSHR molecule involving R531 as a potential $\mathrm{G}_{\mathrm{s}}$-coupling motif. They found that substitution of arginine residue with a glutamine (p.Arg531Glu) resulted in a significant decrease in the basal activity of the receptor but had very little or no effect on the hormone-stimulated cAMP production, and further studies showed that this mutation was structurally conservative. The clinical features observed in our patient 
are consistent with mild TSH resistance and might be attributed to a slight structural change and/or reduced basal activity of the receptor brought about with the mutation.

The severe phenotype associated with exon 2 deletion in family T5 might be explained by the fact that this exon encodes an amino terminal extracellular ligand binding domain of the receptor molecule. Our literature review suggested that homozygous LOF point mutations at the sites encoding the extracellular domain (ECD) of the molecule generally caused mild phenotypes whereas homozygous LOF point mutations in the transmembrane domain were rather associated with severe phenotypes. However our results implicate that gross alterations in the ECD might also severely affect the function of the receptor and thus cause severe phenotypes as observed in our patients.

Overall there is further evidence from our results that TSHR loss-of-function mutations cause a wide spectrum of phenotypic consequences, ranging from a slight TSH resistance to very severe hypothyroidism. Similarly while some deleterious TSHR mutations may result in severe hypoplasia rendering the gland undetectable by initial scintigraphy, some milder mutations may be associated with normal-sized or even slightly enlarged thyroid glands, suspecting defective hormone synthesis. Our findings suggest TSHR mutation testing should be the first investigation in families with suspected non-dyshormonogetic autosomal recessive CHNG. Nevertheless currently known genes seem to account for only a small proportion of CHNG (5\% of all consanguineous kindreds and $25 \%$ of kindreds with two or more affected children) suggesting that further loci for autosomal 
recessive $\mathrm{CHNG}$ remain to be identified and that autozygosity mapping studies in consanguineous families could lead to the identification of novel CHNG genes. 


\section{REFERENCES}

1. Park, S.M. \& Chatterjee, V.K.K. (2005) Genetics of congenital hypothyroidism. Journal of Medical Genetics, 42, 379-389.

2. Kopp, P. (2002) Genetic defects in the etiology of congenital hypothyroidism. Endocrinology, 143, 2019-2024.

3. Sanders, J., Chirgadze, D.Y., Sanders, P. et al. (2007) Crystal structure of the TSH receptor in complex with a thyroid-stimulating autoantibody. Thyroid, 17, 395-410.

4. Li, J., Edwards, P.C., Burghammer, M. et al. (2004) Structure of bovine rhodopsin in a trigonal crystal form. Journal of Molecular Biology, 343, 1409-1438.

5. Van Durme, J., Horn, F., Costagliola, S. et al. (2006) GRIS: glycoprotein-hormone receptor information system. Molecular Endocrinology, 20, 2247-2255.

6. Arnold, K., Bordoli, L., Kopp, J. et al. (2006) The SWISS-MODEL workspace: a web-based environment for protein structure homology modelling. Bioinformatics, 22, 195-201.

7. Fan, Q.R. \& Hendrickson, W.A. (2005) Structure of human follicle-stimulating hormone in complex with its receptor. Nature, 433, 269-277.

8. Liang, Y., Fotiadis, D., Filipek, S. et al. (2003) Organization of the G protein-coupled receptors rhodopsin and opsin in native membranes. Journal of Biological Chemistry, 278, 21655-21662.

9. Topham, C.M., Srinivasan, N. \& Blundell, T.L. (1997) Prediction of the stability of protein mutants based on structural environment-dependent amino acid substitution and propensity tables. Protein Engineering, 10, 7-21. 
10. UniProt Consortium. (2010) The Universal Protein Resource (UniProt) in 2010. Nucleic Acids Research, 38, D142-148.

11. Jain, E., Bairoch, A., Duvaud, S. et al. (2009) Infrastructure for the life sciences: design and implementation of the UniProt website. BMC Bioinformatics, 10, 136.

12. Abramowicz, M.J., Duprez, L., Parma, J. et al. (1997) Familial congenital hypothyroidism due to inactivating mutation of the thyrotropin receptor causing profound hypoplasia of the thyroid gland. Journal of Clinical Investigation, 99, 30183024 .

13. Parmentier, M., Libert, F., Maenhaut, C. et al. (1989) Molecular cloning of the thyrotropin receptor. Science, 246, 1620-1622.

14. Nagayama, Y., Kaufman, K.D., Seto, P. et al. (1989) Molecular cloning, sequence and functional expression of the cDNA for the human thyrotropin receptor. Biochemical and Biophysical Research Communications, 165, 1184-1190.

15. Libert, F., Lefort, A., Gerard, C. et al. (1989) Cloning, sequencing and expression of the human thyrotropin (TSH) receptor: evidence for binding of auto-antibodies. Biochemical and Biophysical Research Communications, 165, 1250-1255.

16. Misrahi, M., Loosfelt, H., Atger, M. et al. (1990) Cloning, sequencing and expression of human TSH receptor. Biochemical and Biophysical Research Communications, 166, 394-403.

17. Stein, S.A., Oates, E.L., Hall, C.R. et al. (1994) Identification of a point mutation in the thyrotropin receptor of the hyt/hyt hypothyroid mouse. Molecular Endocrinology, 8, 129-138. 
18. Gu, W.X., Du, G.G.D., Kopp, P. et al. (1995) The thyrotropin receptor transmembrane domain mutation (Pro 556 Leu) in the hypothyroid hyt/hyt mouse results in plasma membrane targeting but dfective TSH binding. Endocrinology, 136, 3146-3153.

19. Sunthornthepvarakul, T., Gottschalk, M.E., Hayashi, Y. et al. (1995) Resistance to thyrotropin caused by mutations in the thyrotropin-receptor gene. The New England Journal of Medicine, 332, 155-160.

20. Tonacchera, M., Di Cosmo, C., De Marco, G. et al. (2007) Identification of TSH receptor mutations in three families with resistance to TSH. Clinical Endocrinology, 67, 712-718.

21. Refetoff, S. (2003) Resistance to thyrotropin. Journal of Endocrinological Investigation, 26, 770-779.

22. de Roux, N., Misrahi, M., Brauner, R. et al. (1996) Four families with loss of function mutations of the thyrotropin receptor. Journal of Clinical Endocrinology \& Metabolism, 81, 4229-4235.

23. Tonacchera, M., Perri, A., De Marco, G. et al. (2004) Low prevalence of thyrotropin receptor mutations in a large series of subjects with sporadic and familial nonautoimmune subclinical hypothyroidism. Journal of Clinical Endocrinology \& Metabolism, 89, 5787-5793.

24. Costagliola, S., Sunthorntepvarakul, T., Migeotte, I. et al. (1999) Structure-function relationships of two loss-of-function mutations of the thyrotropin receptor gene. Thyroid, 9, 995-1000. 
25. Feng, X., Müller, T., Mizrachi, D. et al. (2008) An intracellular loop (IL2) residue confers different basal constitutive activities to the human lutropin receptor and human thyrotropin receptor through structural communication between IL2 and helix 6, via helix 3. Endocrinology, 149, 1705-1717. 
A

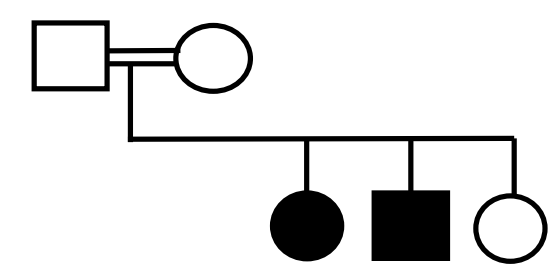

I:1 $\quad$ I:2 II:1 II:2 II:3

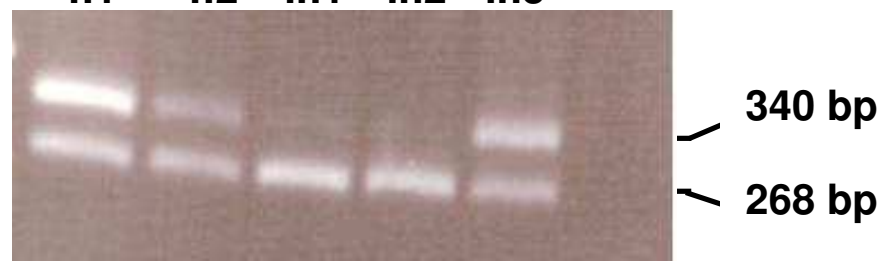

B

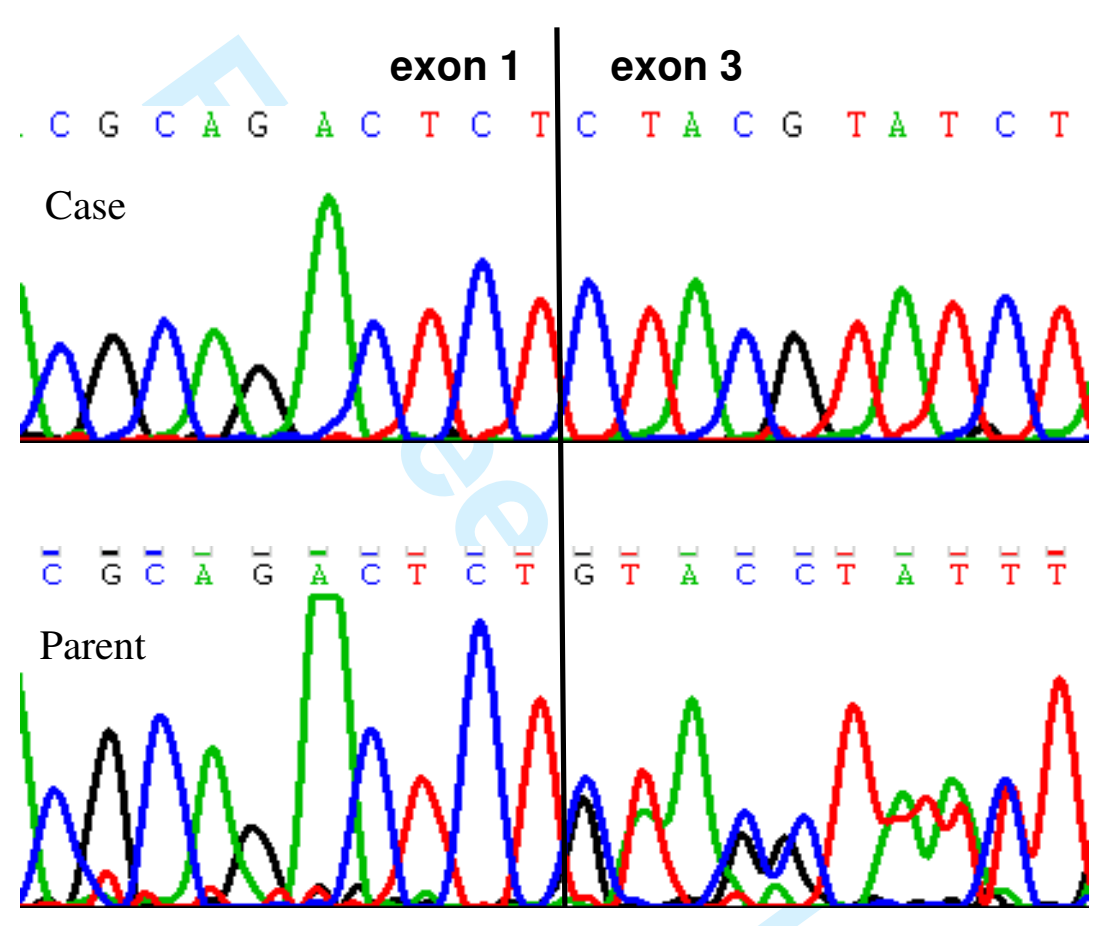

Figure 1. A) Pedigree (upper panel) and TSHR exon 1-3 RT-PCR results (lower panel) in family T5 with two affected cases showing two different-sized fragments, 268-bp and 340-bp. (Note the homozygous state of the bands in affected cases versus heterozygous state in carrier family members). B) Sequence traces of TSHR exon 1-3 cDNA from an affected case (upper panel) and one of her parents (lower panel) representing homozygous and heterozygous states of the deletion, respectively. 


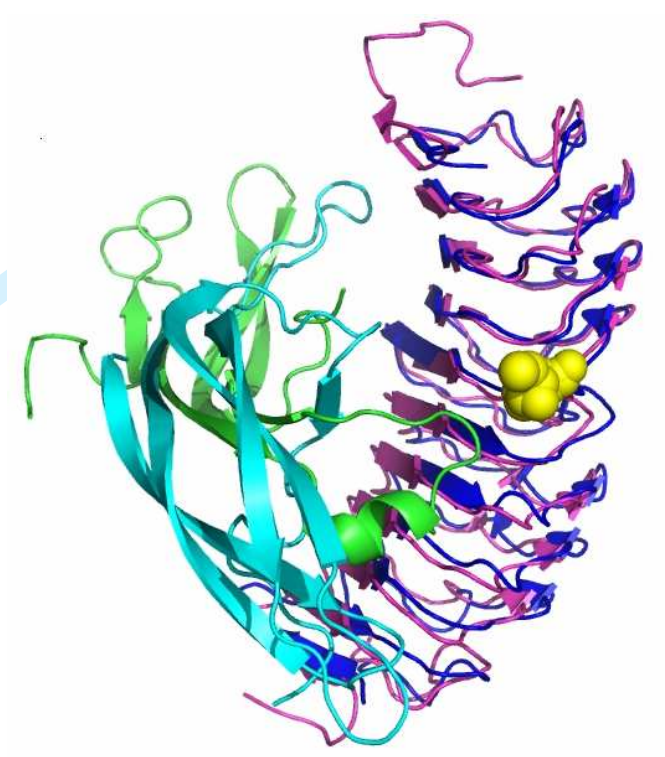

Figure 2. FSH/FSHR complex and TSHR. The hormone binding domains are superimposed (FSHR in magenta, TSHR in blue, FSH in green and cyan) and displayed as a cartoon, and the mutated residue (Pro162 in TSHR, equivalent to Ile155 in FSHR) shown as yellow spheres. 
Figure 3. Bovine rhodopsin dimer structure, displayed as a cartoon. This structure was used to model the effects of the membrane domain mutations in TSHR. The yellow residues, shown as spheres $(146,168,171$, top to bottom in the image), are equivalent to the mutated residues in $\operatorname{TSHR}(531,553,556)$. 
Table 1. Features of known-causative genes for congenital non-goitrous hypothyroidism (CHNG)

\begin{tabular}{|c|c|c|c|c|c|c|}
\hline Gene & $\begin{array}{l}\text { Chromosomal } \\
\text { location } 1\end{array}$ & CHNG locus & Microsatellite markers ${ }^{2}$ & Inheritance & $\begin{array}{l}\text { Thyroid } \\
\text { morphology }\end{array}$ & $\begin{array}{l}\text { Biocemical } \\
\text { spectrum }\end{array}$ \\
\hline TSHR & $14 q 31$ & CHNG1 & $\begin{array}{l}\text { D14S1433, D14S1008, D14S606, } \\
\text { D14S610 }\end{array}$ & AR & $\begin{array}{l}\text { Agenesis- } \\
\text { Normal }\end{array}$ & $\begin{array}{l}\text { High TSH } \\
\text { Low TH to } \\
\text { euthyroid }\end{array}$ \\
\hline PAX8 & $2 q 12-q 14$ & CHNG2 & $\begin{array}{l}\text { D2S2269, D2S160, D2S410, } \\
\text { D2S1893 }\end{array}$ & $\begin{array}{l}\text { AR, AD with } \\
\text { variable } \\
\text { expressivity }\end{array}$ & $\begin{array}{l}\text { Agenesis, } \\
\text { hemiagenesis, } \\
\text { hypoplasia, } \\
\text { ectopy }\end{array}$ & $\begin{array}{l}\text { High TSH } \\
\text { Low to normal } \\
\text { TH }\end{array}$ \\
\hline TSHB & $1 \mathrm{p} 13$ & CHNG4 & $\begin{array}{l}\text { D1S2756, D1S2881, D1S2852, } \\
\text { D1S189 }\end{array}$ & AR & Hypoplasia & $\begin{array}{l}\text { Variable TSH } \\
\text { Low TH }\end{array}$ \\
\hline NKX2-5 & $5 q 34$ & CHNG5 & $\begin{array}{l}\text { D5S400, D5S2075, D5S211, } \\
\text { ATA52D02 }\end{array}$ & $\mathrm{AD} ?$ & Hypoplasia & $\begin{array}{l}\text { High TSH } \\
\text { Low TH }\end{array}$ \\
\hline
\end{tabular}

${ }^{1}$ Location according to USCS Genome Bioinformatics (http://zeon.well.ox.ac.uk/HumanGenome)

${ }^{2}$ Sequences available from Genome Database at http://www.ncbi.nlm.nih.gov/sites/entrez?db=unists

$\mathrm{AR}$, autosomal recessive; $\mathrm{AD}$, autosomal dominant; $\mathrm{TH}$, thyroid hormones 
Table 2. Number of patients at each locus in whom linkage could not be excluded.

\begin{tabular}{|l|c|c|c|c|c|}
\hline \multirow{2}{*}{ Population } & \multicolumn{5}{|c|}{ CHNG loci } \\
\cline { 2 - 6 } & TSHR & TSHB & PAX & NKX2-5 & CHNG3 \\
\hline $\begin{array}{l}\text { All } \\
(\mathrm{n}=139)\end{array}$ & 24 & 17 & 15 & 9 & 9 \\
\hline $\begin{array}{l}\text { Pakistani Cases } \\
(\mathrm{n}=44)\end{array}$ & 10 & 8 & 5 & 6 & 2 \\
\hline $\begin{array}{l}\text { Turkish Cases } \\
(\mathrm{n}=95)\end{array}$ & 14 & 9 & 10 & 3 & 7 \\
\hline
\end{tabular}


Table 3: Details of TSHR mutations detected in 6 kindreds with congenital hypothyroidism.

\begin{tabular}{|l|l|l|l|l|c|c|c|l|}
\hline $\begin{array}{l}\text { Family } \\
\text { ID }\end{array}$ & $\begin{array}{l}\text { Ethnic } \\
\text { origin }\end{array}$ & $\begin{array}{l}\text { Nucleotide } \\
\text { change }\end{array}$ & $\begin{array}{l}\text { Protein } \\
\text { change }\end{array}$ & $\begin{array}{l}\text { Mutation } \\
\text { type }\end{array}$ & Exon & $\begin{array}{l}\text { Previously } \\
\text { reported? }\end{array}$ & $\begin{array}{l}\text { Number of } \\
\text { affected } \\
\text { individuals }\end{array}$ & Phenotype \\
\hline B1 & Pakistani & c.1657G $>$ C & p.Ala553Thr & Missense & 10 & Yes & 2 & $\begin{array}{l}\text { Severe thyroid } \\
\text { hypoplasia }\end{array}$ \\
\hline T1 & Turkish & c.317+1G $>$ A & $? ? ?$ & splice & - & No & 2 & $\begin{array}{l}\text { Thyroid } \\
\text { aplasia }\end{array}$ \\
\hline T2 & Turkish & c.1667C $>$ G & p.Pro556Arg & Missense & 10 & No & 1 & $\begin{array}{l}\text { Thyroid } \\
\text { aplasia }\end{array}$ \\
\hline T3 & Turkish & c.484C>G & p.Pro162Ala & Missense & 6 & Yes & 1 & $\begin{array}{l}\text { Moderate TSH } \\
\text { resistance }\end{array}$ \\
\hline T4 & Turkish & c.1591C>T & p.Arg531Trp & Missense & 10 & No & 1 & $\begin{array}{l}\text { Mild TSH } \\
\text { resistance }\end{array}$ \\
\hline T5 & Turkish & $\begin{array}{l}\text { Deletion } \\
\text { exon 2 }\end{array}$ & $? ? ?$ & $\begin{array}{l}\text { Exon2 } \\
\text { deletion }\end{array}$ & 2 & No & 2 & $\begin{array}{l}\text { Severe thyroid } \\
\text { hypoplasia }\end{array}$ \\
\hline
\end{tabular}


Table 4. Structural prediction scores calculated by the software tool $\mathrm{SDM}^{9}$

\begin{tabular}{|l|l|r|c|}
\hline 3G04 $^{\text {a }}$ & & \multicolumn{2}{|c|}{ SDM prediction } \\
\hline Pro162Ala & & -0.72 & neutral \\
\hline TSHR & 1GZM $^{\text {b }}$ & \multicolumn{2}{|c|}{ SDM predictions } \\
\hline Arg531Trp & F146W & 1.25 & neutral \\
\hline Arg531Glu & F146Q & -2.08 & disease-associated \\
\hline Ala553Thr & A168T & -2.65 & disease-associated \\
\hline Pro556Arg & P171R & 0.69 & neutral \\
\hline Pro556Leu & P171L & 3.45 & disease-associated \\
\hline
\end{tabular}

${ }^{a}$ PDB code for the extracellular domain of TSHR molecule based on crystal structure as resolved by Sanders et al. ${ }^{3}$

${ }^{\mathrm{b}} \mathrm{PDB}$ code for bovine rhodopsin molecule. Equivalent residues corresponding to the mutation sites in TSHR molecule are indicated and prediction scores are based on alterations in these residues. 